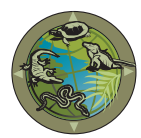

\title{
New Locality Record of the Lined Stripe- necked Snake, Liopeltis calamaria (Günther 1856) (Squamata: Colubridae) from Nepal
}

\author{
Santosh Bhattarai ${ }^{1}$, Chiranjibi Prasad Pokheral ${ }^{2}$, and Naresh Subedi ${ }^{3}$ \\ ${ }^{1}$ National Trust for Nature Conservation, Biodiversity Conservation Center, Ratnanagar-06, Sauraha, Chitwan-44204, Nepal (santosh.bhattarai@hotmail.com) \\ ${ }^{2}$ National Trust for Nature Conservation, Central Zoo, Jawalakhel, Lalitpur, Nepal \\ ${ }^{3}$ National Trust for Nature Conservation, Khumaltar, Lalitpur, Nepal
}

$T^{1}$ he Lined Stripe-necked Snake (Liopeltis calamaria) was long thought to be distributed solely in Sri Lanka and India (e.g., Chunekar and Alekar 2015) until Bhattarai et al. (2017a) recorded L. calamaria for the first time from Dhodeni, Kabilas, Chitwan in Nepal in degraded agricultural land. At 1309 h on 13 March 2018, we encountered a snake (Fig. 1) moving along a forest trail at Gairigaun, Makwanpur, Nepal $\left(27.39752^{\circ} \mathrm{N}, 85.38385^{\circ} \mathrm{E}\right.$, WGS 1984; elev. $825 \mathrm{~m}$; Fig. 2). The snake was brown, slender-bodied, smooth-scaled, and had large round pupils; it was $208 \mathrm{~mm}$ in total length, dorsal scale rows numbered 15:15:15, ventrals 140, and subcaudals 68. It had one preocular, two postoculars, seven supralabials with the 3rd and 4th in contact with the eye, and the nasal was not divided. Scalation corresponded to descriptions of Liopeltis calamaria in Smith (1943). After identification by the first author, a digital photo voucher (ZRC(IMG) 2.386) was deposited at the Lee Kong Chian Natural History Museum, National University of Singapore. The snake was released at the site of capture.

Liopeltis calamaria is a terrestrial, diurnally active snake reportedly found in dry tropical forests aassociated with plateaus (Narayanan 2016). In Nepal, this species has been recorded from only two locations, both in severely altered habitats. The new location was a degraded Sal (Shorea robusta) forest approximately $100 \mathrm{~km}$ east of the earlier record (Bhattarai et al. 2017a). The snake was near a village

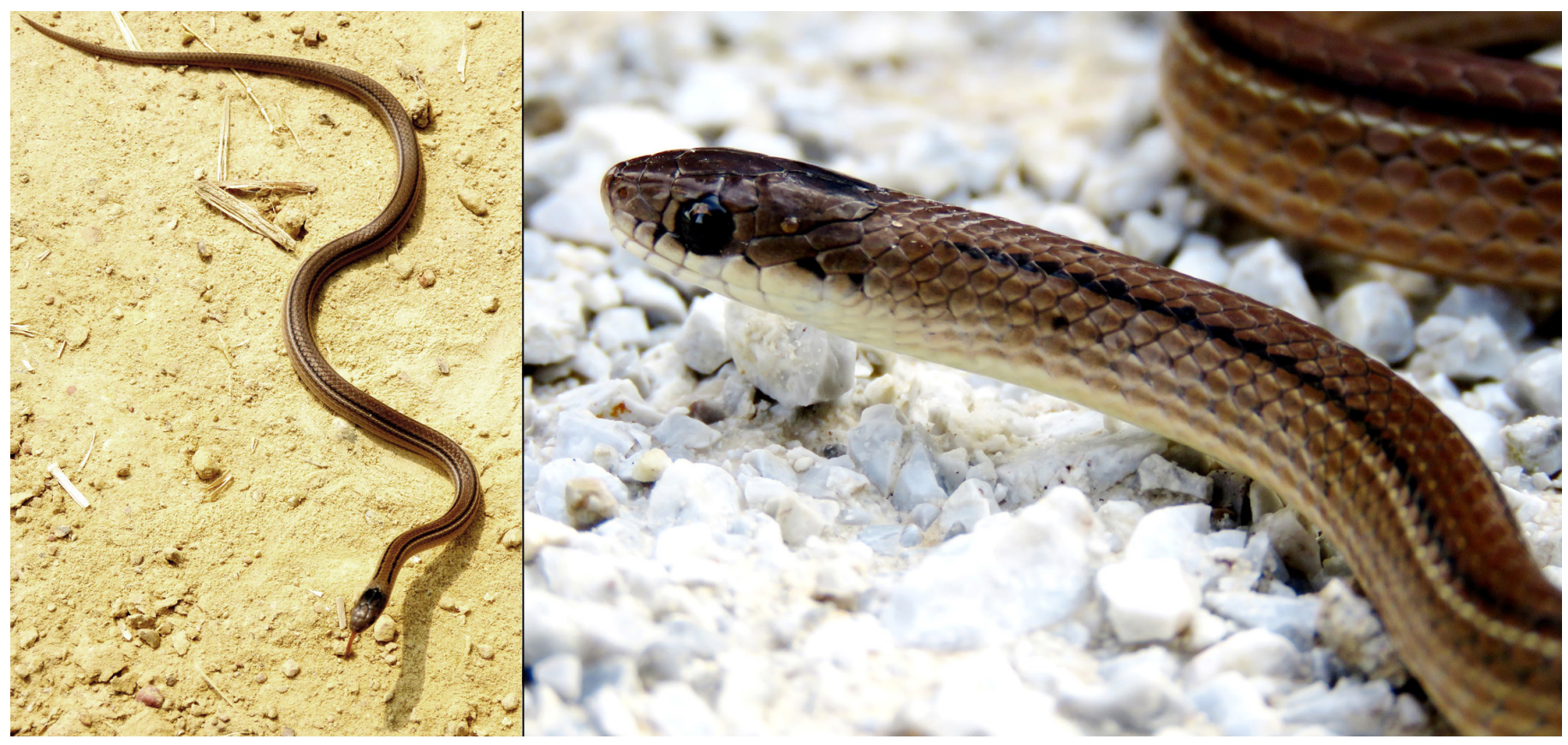

Fig. 1. Dorsum (left) and lateral view of the head (right) of a Lined Stripe-necked Snake (Liopeltis calamaria) encountred at Gairigaun, Makwanpur, Nepal. Photograph by Santosh Bhattarai. 


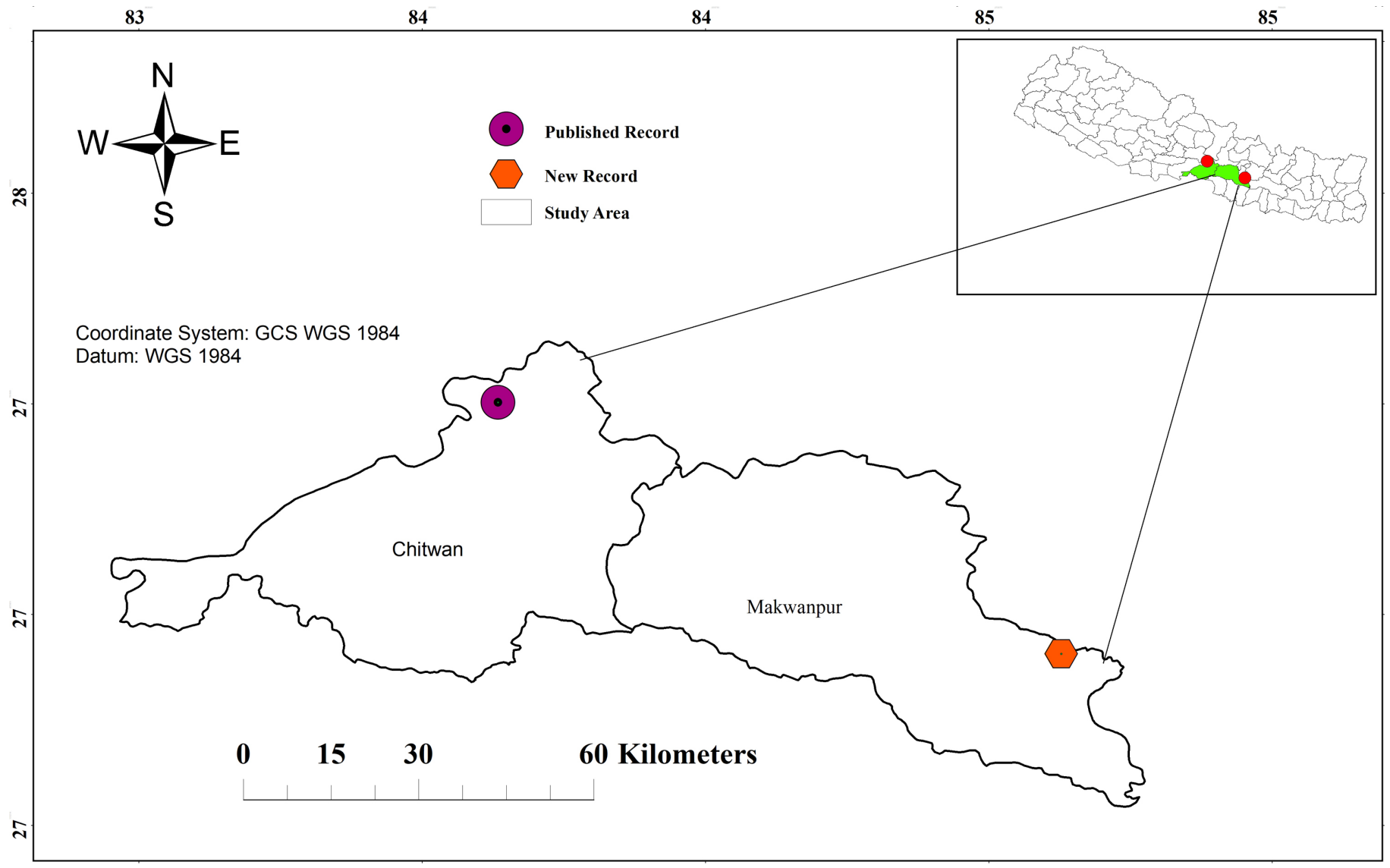

Fig. 2. Locality records of the Lined Stripe-necked Snake (Liopeltis calamaria) in Nepal.

where people perceive all snakes to be venomous and kill them whenever they are encountered (Bhattarai et al. 2017b; Sharma et al. 2013). This species is likely to have wider distribution in Nepal. We suggest a detailed inventory be implemented to establish its distribution, ecology, and conservation threats. This species has not yet been assessed for the IUCN Red List.

\section{Acknowledgements}

We thank Om P. Chaudhary, Wildlife Technician for his help in the field and the staff of the National Trust for Nature Conservation-Biodiversity Conservation Center for logistical support. We also are grateful to Sujan Khanal for preparation of the map. This observation was made during a biodiversity survey in Makwanpur by NTNC-BCC, Sauraha, Chitwan, Nepal.

\section{Literature Cited}

Bhattarai, S., L. Chalise, A. Gurung, C.P. Pokheral, N. Subedi, and V. Sharma. 2017a. Geographic distribution: Liopeltis calamaria (Lined Stripe-necked Snake). Herpetological Review 48: 129.

Bhattarai, S., K.B. Thapa, L. Chalise, A. Gurung, C.P. Pokheral, N. Subedi, T.B. Thapa, and K.B. Shah. 2017b. On the distribution of the Himalayan Stripenecked Snake Liopeltis rappi (Günther, 1860) (Serpentes: Colubridae) in Nepal. Amphibian \& Reptile Conservation 11: 88-92.

Chunekar, H. and S. Alekar. 2015. Range extension of the Calamaria Reed Snake, Liopeltis calamaria (Günther 1858) from the Western Ghats, Maharashtra, India. Reptiles \& Amphibians 22: 79-80.

Narayanan, S. 2016. On the occurrence of the Calamaria Reed Snake Liopeltis calamaria (Günther, 1858) (Squamata: Colubridae), in the Kalakadu Mundanthurai Tiger Reserve, India. Reptile Rap 18: 29-30.

Sharma, S.K., D.P. Pandey, K.B. Shah, F. Tillack, F. Chappuis, C.L. Thapa, E. Elirol, and U. Kuch. 2013. Venomous Snakes of Nepal: A Photographic Guide. B.P. Koirala Institute of Health Sciences, Dharan, Nepal.

Smith, M.A. 1943. The Fauna of British India, Ceylon and Burma, Including the Whole of the Indo-Chinese Sub-Region. Reptilia and Amphibia. Volume IIISerpentes. Taylor and Francis, London. 